\title{
PENGARUH pH DAN WAKTU FERMENTASI UNTUK MENGHASILKAN ENZIM AMILOGLUKOSIDASE DARI Aspergillus niger
}

\author{
Fatmawati Nur \\ Jurusan Biologi UIN Alauddin Makassar \\ E-mail: fatenurkhalik@yahoo.com
}

\begin{abstract}
This study is aimed to know the ability of Aspergillus niger in producing amyloglucosidase enzyme through fermentation technology by exploiting marquisa waste's peel and coated seed under the condition of variation $\mathrm{pH}$ and fermentation time. Design used is Randomized Complete Block along with the respective variation of $\mathrm{pH}$ is $\mathrm{pH}$ 4.0, 4.5, 5.0, and 5.5, through fermentation time is 3, 4, 5, and $6 \times 24$ hours, duplo, which is analyzed with $F$ test, then tested with Least Significant Difference (LSD). The result of study shows the highest glucose concentration representing job of amyloglucosidase enzyme at coated seed substract is fermentation time $5 \times 24$ hours $\mathrm{pH} 4.5$ which amounts $51.964 \mu \mathrm{g} / \mathrm{ml}$.
\end{abstract}

Keywords: Amyloglucosidase enzyme, Fermentation time, Marquisa waste, $p H$

\section{PENDAHULUAN}

S etiap kegiatan industri senantiasa berkaitan dengan berbagai transaksi, aktivitas lain, dan memberikan pengaruh terhadap lingkungan. Industri merupakan integrasi seluruh proses fisika kimia yang mentransformasikan bahan baku, energi, dan tenaga kerja menjadi produk dan limbah. Limbah industri merupakan suatu produk industri yang belum memiliki nilai ekonomi dan biasanya terbuang percuma ke lingkungan.

Di Sulawesi Selatan, salah satu industri yang berkembang dengan baik adalah industri sari buah markisa yang ditopang oleh keberadaan perkebunan markisa baik dari jenis markisa ungu (Passiflora edulis) maupun markisa kuning/konyal (Passiflora ligularis) dari daerah-daerah produsen utama: Gowa, Tana Toraja, Sinjai dan Bantaeng (Studi Suplai Industri Markisa Di Sulawesi Selatan, 2009). Industri ini memproduksi sirup markisa untuk konsumsi domestik bahkan dieksport ke beberapa negara. Untuk kepentingan produksi dibutuhkan buah markisa dalam jumlah yang sangat besar setiap bulannya.

Limbah markisa yang berupa kulit, biji, dan selaput biji dalam jumlah yang sangat besar setiap hari dibuang pada suatu tempat terbuka dan bertumpuk, bahkan ada yang terbuang ke perairan. Hal ini menyebabkan lingkungan tercemar dan menjadi masalah pokok dalam kehidupan. Limbah ini dapat menjadi sumber penyakit dan menimbulkan bau yang tidak sedap bagi lingkungan sekitarnya karena pada kulit markisa yang terbuang terdapat selaput pembungkus biji yang sangat gampang ditumbuhi oleh mikroorganisme pembusuk.

Walaupun demikian, limbah markisa seyogyanya dapat dianggap sebagai sumber daya tambahan yang dapat dimanfaatkan, termasuk dijadikan medium fermentasi mikroorganisme mengingat buangan limbah industri ini masih mengandung bahan organik dan nutrien utamanya polisakarida/BETN (Bahan Ekstrak Tanpa Nitrogen). Kulit buah markisa mengandung BETN 
49.60\%, biji markisa yang berwarna hitam mengandung BETN 18.87\%, dan selaput pembungkus biji yang berwarna kuning mengandung BETN 49.90\% (Djarre, 1994).

Molekul-molekul sederhana seperti gula dan komponen lain yang larut di sekelilingnya dapat langsung digunakan. Molekul-molekul lain yang lebih kompleks seperti Bahan Ekstrak Tanpa Nitrogen (polisakarida) sebagai sumber karbon yang masih terdapat di dalam substrat harus dipecah dahulu sebelum diserap ke dalam sel (Hardjo, Indrasti, dan Bantacut, 1989). Untuk memecahkan molekul besar menjadi sederhana, mikroorganisme mengeluarkan enzim tertentu ke lingkungannya sesuai dengan jenis zat yang akan diuraikan. Enzim yang dikeluarkan oleh mikroorganisme ke lingkungan, lazim disebut enzim ekstraselluler (Smith, 1993).

Salah satu enzim ekstraselluler yang dapat memecahkan senyawa kompleks polisakarida adalah enzim amiloglukosidase yang sangat penting digunakan dalam bidang produksi alkohol, roti, juice, dan pati (Rahman, 1992). Mikroorganisme yang dapat menghasilkan enzim ini telah diujikan melalui penelitian dengan proses isolasi dan penapisan jamur penghasil amiloglukosidase dari limbah tapioka. Didapatkan bahwa isolat terbaik adalah Aspergillus oryzae, Aspergillus sydowi, dan Aspergillus niger. Produksi glukosa tertinggi dihasilkan oleh ubi jalar yang diinokulasi dengan ekstrak kasar enzim dari Aspergillus niger (Indriani, 2008).

Melihat potensi limbah dan mikroorganisme seperti tersebut di atas, maka penggunaan limbah markisa sebagai medium fermentasi oleh Aspergillus niger untuk menghasilkan enzim amiloglukosidase selain mengurangi jumlah limbah markisa dalam upaya mengatasi pencemaran lingkungan, juga dapat memberikan sumbangan informasi untuk industri mikrobial.

Tujuan penelitian ini adalah untuk mengetahui potensi kandungan nutrien dalam limbah markisa dan bagian buah markisa yang paling bagus dimanfaatkan oleh Aspergillus niger sebagai medium fermentasi untuk menghasilkan enzim amiloglukosidase.

\section{Limbah Markisa}

Buah markisa (siuh) termasuk buah buni (bacca), adalah buah dengan dua lapisan, yaitu lapisan luar yang tipis agak menjangat atau kaku, dan lapisan dalam yang tebal, lunak dan berair. Biji-biji terdapat bebas dalam bagian yang lunak. Buah yang tidak begitu tebal kulit buahnya seringkali mempunyai sifat agak kaku seperti kulit, tidak lunak, dan tidak berdaging, biji bebas di dalam, yang dimakan adalah selaput biji (arillus) (Popenoe, 1974).

Kulit buahnya tipis, liat. Bagian dalam diliputi lapisan (endocarp) yang putih warnanya. Data penelitian menunjukkan bahwa buah markisa terdiri atas kulit $51 \%$ dan isi $49 \%$ yang terbagi atas biji 20.2\% dan sari buah 28.8\% (Syamsu, 2009). Biji banyak, hitam warnanya, dilapisi dengan selaput (arillus) yang asam manis rasanya dan harum semerbak baunya, mengandung $12 \%$ protein, $18 \%$ gula, vitamin $\mathrm{A}$, vitamin $\mathrm{B} 1$, dan vitamin $\mathrm{C}$, sehingga banyak diproduksi menjadi sirup, soda, jelly, dan selei (Wood and Sinnluh, 1986).

Bahan buangan berupa kulit, biji, dan selaput yang masih mengandung air, protein, lemak, serat, karbohidrat, serta mineral, telah diusahakan pengolahannya. Kulit buah markisa kering yang memiliki kandungan gizi bahan kering $88.38 \%$ dengan protein kasar 8.43\%, NDF 55.95\%, ADF $37.98 \%$ dan hemiselulosa $17.97 \%$ diolah menjadi makanan ternak (Syamsu, 2009), sedangkan endocarp yang mengandung pektin dapat dijadikan bahan untuk jelly (Rismunandar, 1986).

Kulit buah markisa mengandung air $17.09 \%$, protein $6.98 \%$, lemak $1.25 \%$, serat 34.78\%, Bahan Ekstrak Tanpa Nitrogen 49.60\%, abu 7.39\%, Ca 0.12\%, dan P 0.88\% . Biji markisa yang berwarna hitam mengandung air 9.15\%, protein $9.18 \%$, lemak $23.96 \%$, serat 46.34\%, Bahan Ekstrak Tanpa Nitrogen 18.87\%, abu 1.65\%, Ca 0.08\%, dan P 2.56\%. Selaput pembungkus biji yang berwarna kuning mengandung air $10.36 \%$, protein $17.35 \%$, lemak 
10.08\%, serat 18.77\%, Bahan EkstrakTanpa Nitrogen 49.90\%, abu 3.90\%, Ca 0.14\%, dan P $3.07 \%$ (Djarre, 1994).

\section{Aspergillus niger}

Aspergillus terdapat dimana-mana, baik di daerah kutub maupun daerah tropik, dan hampir pada semua substrat. Disamping adanya species yang patogen, ada pula species yang dimanfaatkan oleh manusia dalam perindustrian. Aspergillus banyak digunakan dalam studi tentang enzimologi, biokimia, pembuatan asam sitrat, asam glukonat, dan beberapa asam organik lainnya (Dwijosepoetro, 1978).

Aspergillus niger merupakan salah satu spesies yang paling umum dan mudah diidentifikasi dari genus Aspergillus, famili Moniliaceae, ordo Monoliales dan kelas Fungi imperfecti. Aspergillus niger dapat tumbuh dengan cepat, diantaranya digunakan secara komersial dalam produksi asam sitrat, asam glukonat dan pembuatan berapa enzim seperti amilase, pektinase, amiloglukosidase dan sellulase (Aspergillus niger, 2007).

Mengenai morfologinya, bahwa ciri khas yang dimiliki kapang ini ialah cara bagaimana konidia terbentuk, sedang untuk membedakan species yang satu dengan yang lainnya digunakan terutama kriteria warna (Dwijosepoetro, 1978). Miselium Aspergillus terdiri atas hifa bersekat-sekat, berinti banyak. Pembentukan konidia dimulai dari ujungujung hifa yang tumbuh menegak. Pada pangkal hifa terdapat suatu alas yang disebut sel kaki. Pada suatu waktu ujung dari hifa yang menegak ini menggelembung merupakan vesikel. Pada permukaan vesikel tumbuh tubuh buah berupa botol yang umumnya menghasilkan konidia. Pembentukan konidia dimulai dari ujung, jadi konidia yang paling tua ialah konidia yang paling ujung. Sel-sel penghasil konidia disebut sterigma. Bagian hifa di bagian bawah vesikel sampai ke kaki disebut konidiophora (Dwijosepoetro, 1978).

Aspergillus niger memiliki bulu dasar berwarna putih atau kuning dengan lapisan konidiospora tebal berwarna coklat gelap sampai hitam. Kepala konidia berwarna hitam, bulat, cenderung memisah menjadi bagian-bagian yang lebih longgar dengan bertambahnya umur. Konidiospora memiliki dinding yang halus, hialin tetapi juga berwarna coklat (Aspergillus niger, 2007).

Kenampakan konidiophora berupa panjang pendek, besar kecil, serta halus kasarnya, menjadi kriteria dalam pembedaan species. Begitu pula halnya keragaman konidia terutama dalam hal warna dan ukuran. Konidia berbentuk bulat dapat ditemukan pada Aspergillus niger, hemisperikel pada Aspergillus tricola, elips pada Aspergillus elevatus, dan bentuk kolumnar pada Aspergillus flavus (Prescott, 1959).

Seperti halnya mikroorganisme yang lain, Aspergillus niger memiliki kurva pertumbuhan dengan tiga fase yang berbeda, yakni masing-masing fase awal (lag phase), fase eksponensial (log phase), dan fase stasioner. Fase awal adalah sejak inolukasi sel pada medium dan merupakan periode adaptasi. Selama fase ini massa sel dapat berubah tanpa adanya suatu perubahan jumlah sel. Fase logaritmik/fase ekponensial dicirikan oleh suatu garis lurus antara Ln X melawan waktu. Periode ini adalah keadaan pertumbuhan yang seimbang atau mantap, dengan laju pertumbuhan spesifik, konstan. Fase stasioner terjadi bila seluruh sel berhenti membagi diri atau bilamana sel-sel hidup telah mencapai keseimbangan dengan sel-sel mati, yakni dengan kecepatan kematian. Meskipun pertumbuhan telah terhenti, metabolisme dan akumulasi produk masih terjadi. Massa sel total dapat tetap konstan, tetapi jumlah sel hidup cenderung menurun. Pada saat ketahanan hidup menurun, lisis mungkin terjadi dan massa sel akan menurun (Sa'id, 1987). 


\section{Enzim Amiloglukosidase}

Enzim ialah senyawa protein yang disintesiskan di dalam sel secara biokimiawi. Enzim berperan sebagai katalisator pada reaksi kimia yang berlangsung dalam organisme, memiliki sifat dan spesifikasi tertentu (Gaman and Sherrington, 1992). Komponen enzim dapat berupa protein murni atau gabungan antara protein dengan gugus kimiawi lainnya. Bagian enzim yang terdiri dari protein bersifat termolabil (tidak tahan panas) diberi nama apoenzim. Sedangkan bagian lain yang bukan protein bersifat termostabil (tahan panas) diberi nama gugus prostetik (bagian yang aktif). Apoenzim dengan gugus prostetik merupakan satu kesatuan yang disebut holoenzim (Kertesz and Collogen, 1976).

Bagian gugus prostetik terdiri dari molekul organik yang berat molekulnya lebih rendah daripada apoenzim, dinamakan koenzim. Beberapa enzim mengandung vitamin sebagai pelengkap. Tetapi dalam beberapa hal, bagian gugus prostetik suatu enzim berupa logam untuk menjadi teraktivasi. Ion-ion itu dianggap sebagai koenzim anorganik (kofaktor), dan keduanya dibutuhkan untuk membuat suatu enzim menjadi aktif (Pelczar dan Chan, 2006).

Beberapa karakteristik enzim yaitu, setiap reaksi metabolisme di dalam sel maupun di luar sel akan berperan enzim-enzim tertentu dan spesifik. Artinya, enzim bersifat spesifik dalam melaksanakan fungsinya, enzim dapat digunakan berulangulang. Kerja setiap enzim spesifik pada kisaran suhu tertentu (tidak bekerja pada suhu ekstrim) dan $\mathrm{pH}$ tertentu. Maka kerja enzim dipengaruhi oleh suhu dan $\mathrm{pH}$. Kerja enzim juga dipengaruhi oleh substratnya (Apa dan Bagaimana: Tentang Enzim, 2009).

Enzim merupakan biokatalis yaitu senyawa yang diproduksi oleh organisme. Secara garis besar sumber enzim dapat digolongkan menjadi tiga, yaitu hewan, tanaman dan mikroorganisme. Namun saat ini, enzim yang diproduksi dalam skala industri sebagian besar diperoleh dari mikroorganisme (Apa dan Bagaimana: Tentang Enzim, 2009). Dari sumber tumbuhan dan hewan mungkin timbul banyak persoalan, yakni untuk enzim yang berasal dari tumbuhan, persoalan yang timbul adalah variasi musim, konsentrasi rendah dan biaya proses yang tinggi. Sedangkan yang diperoleh dari hasil samping industri daging mungkin persediaan enzimnya terbatas dan ada persaingan dengan pemanfaatan lain (Smith, 1993). Selain itu, jaringan tanaman maupun hewan mengandung bahan yang kemungkinan berbahaya seperti senyawa fenolik (pada tanaman), inhibitor enzim dan protase (Apa dan Bagaimana: Tentang Enzim, 2009).

Oleh karena itu peningkatan sumber enzim sedang dilakukan yaitu mikroorganisme penghasil enzim yang sudah dikenal atau penghasil enzim baru lainnya, dengan cara membiakkan mikroorganisme penghasil enzim yang dikehendaki pada medium tertentu kemudian diekstraksi dan akhirnya dimurnikan. Sebagai sumber enzim, mikroorganisme memiliki beberapa kelebihan jika dibandingkan dengan hewan maupun tanaman, yaitu : produksi enzim pada mikroorganisme lebih murah, kandungan enzim dapat diprediksi dan dikontrol, pasokan bahan baku terjamin, dengan komposisi konstan dan mudah dikelola. Selain itu, enzim mikroorganisme ada yang disekresikan ke luar sel sehingga memudahkan proses isolasi dan pemurniannya (Smith, 1993). Setidaknya ada 3 keuntungan yang berkaitan dengan enzim ekstra sel : pertama, tidak memerlukan proses penghancuran sel saat memanen enzim (proses penghancuran sel tidak selalu mudah dilakukan dalam skala besar). Kedua, enzim protein yang disekresikan keluar sel umumnya terbatas jenisnya. Ini berarti enzim ekstrim sel terhindar dari kontaminasi berbagai jenis protein. Ketiga, secara alami enzim disekresikan keluar sel umumnya lebih tahan terhadap proses denaturasi (Apa dan Bagaimana: Tentang Enzim, 2009). 


\section{Faktor-faktor Penting untuk Produksi Enzim}

Untuk keberhasilan sebuah proses fermentasi, ada beberapa faktor penting yang harus diperhatikan untuk fermentasi enzim sebagai berikut (Sa'id, 1987) :

1. Seleksi Strain

Pada saat merancang fermentasi enzim, hal yang penting untuk dikerjakan adalah menggunakan strain mikroorganisme yang paling aktif yang tersedia. Jika strain tidak tersedia, maka harus dilakukan seleksi strain dengan mengambil kultur dari alam atau dari koleksi kultur dan melakukan pengujian-pengujian aktivitas enzim.

Mikroorganisme adalah kunci keberhasilan atau kegagalan suatu fermentasi. Oleh karena itu mikroorganisme yang digunakan harus memiliki keunggulan yang diperlukan untuk keberhasilan suatu proses fermentasi. Ciri-ciri di bawah ini perlu dimiliki oleh strain mikroorganisme yang superior, yaitu :

- Strain sel tersebut harus merupakan kultur yang murni, bukan hanya bebas dari mikroorganisme-mikroorganisme lain, tetapi juga harus bebas dari faga.

- Secara genetik, strain tersebut harus stabil.

- Strain tersebut harus siap dapat memproduksi berbagai sel vegetatif, spora, atau unit-unit reproduktif lainnya. Khusus untuk kasus Basidiomycetes, karena hanya menghasilkan miselium, maka jarang digunakan dalam industri fermentasi.

- Strain tersebut harus mampu tumbuh dengan cepat dan kuat sesaat seteiah diinokulasi pada tangki pembibitan, atau wadah lain yang digunakan untuk mempersiapkan suatu industri fermentasi.

- Strain tersebut harus dapat menghasilkan produk yang diinginkan dalam jangka waktu yang pendek.

- Jika memungkinkan, strain tersebut hendaknya mampu melindungi dirinya sendiri dari kontaminasi. Cara melindungi dirinya sendiri dapat berupa penurunan $\mathrm{pH}$, mampu tumbuh pada suhu tinggi, atau mampu dengan cepat menghasilkan suatu inhibitor mikrobial yang diinginkan.

- Strain tersebut harus mampu disimpan untuk jangka waktu yang lama sekali.

- Strain tersebut hendaknya mampu memproduksi produk yang diinginkan, tanpa menghasilkan produk lain yang bersifat beracun (senyawaan beracun). Produk yang diinginkan tersebut harus dapat dengan mudah dipisahkan dari senyawaan-senyawaan atau bahan-bahan lainnya.

- Strain tersebut hendaknya mudah menerima perubahan oleh bahan-bahan mutagenik tertentu. Program mutasi dapat dilakukan dengan tujuan untuk mengembangkan strain tersebut sehingga mampu meningkatkan prdoduksinya.

2. Perbaikan Fermentasi

Bilamana sebuah strain mikroorganisme yang baik telah diperoleh, paramater-parameter fermentasi harus diatur sampai titik optimum untuk memaksimumkan pertumbuhan dan produksi enzim. Diantara parameter yang penting adalah suhu, $\mathrm{pH}$, dan transfer oksigen. Hal penting lainnya adalah nutrien untuk mikroorganisme, khususnya senyawaan yang mengandung karbon, nitrogen, fosfor, sulfur dan garam-garam mineral.

Seringkali penambahan surfaktan (senyawa aktif permukaan) diperlukan, khususnya bila enzim yang diproduksi adalah enzim-enzim ekstraselluler. Surfaktan-surfaktan non ionik umumnya lebih disukai dari senyawaan amoniak atau kationik yang dapat menyebabkan keracunan pada mikroorganisme.

3. Pengenalan puncak siklus pertumbuhan

Bilamana fermentasi dilaksanakan dengan sistem kultur batch, urutan-urutan siklus pertumbuhan yang mengandung konsentrasi enzim yang tinggi haruslah diketahui. Pada 
beberapa kasus, produksi enzim dengan cepat menghilang setelah mencapai aktivitas puncaknya. Di lain pihak, sebuah kemostat dapat lebih berguna untuk prcduksi enzim, karena beberapa pembentukan enzim dapat dikontrol kecepatan pertumbuhannya, yang dapat dijaga konstan pada kultur sinambung.

\section{METODE PENELITIAN}

Penelitian dilakukan dalam beberapa tahapan yang tujuannya mengarah kepada potensi limbah yang berupa kulit dan selaput biji markisa sebagai medium fermentasi Aspergillus niger sehingga menghasilkan enzim amiloglukosidase dengan perlakuan kombinasi $\mathrm{pH}$ dan waktu fermentasi yang bervariasi. Urutan tahapan penelitian sebagai berikut :

1. Sterilisasi Alat dan Bahan

Alat dari gelas disterilkan pada oven suhu $180{ }^{\circ} \mathrm{C}$ selama 2 jam. Sedangkan alat dari logam seperti ose dan jarum spoit disterilkan pada lampu spiritus. Untuk Sterilisasi medium dilakukan pada otoklaf suhu $121^{\circ} \mathrm{C}$ tekanan 2 atm selama 15 menit.

2. Penyiapan Medium PDA (Potato Dextrose Agar)

Medium PDA disterilkan pada otoklaf $121^{\circ} \mathrm{C}$ tekanan 2 atm selama 15 menit. Dimasukkan ke dalam botol roux, ditutup dengan kapas, dan dimiringkan dalam keadaan masih panas sampai agar membeku.

3. Pengolahan Limbah Markisa

Selaput biji dan kulit dikeringkan di bawah sinar matahari, kemudian dihaluskan menjadi tepung untuk keperluan medium fermentasi.

4. Pembuatan Inokulum

Aspergillus niger yang ditumbuhkan pada medium PDA umur 4 × 24 jam suhu kamar, ditambahkan cairan yang terdiri dari $0.1 \%$ tween 80 dan $0.9 \% \mathrm{NaCI}$ fisiologis, kemudian dikeruk dan dikocok hingga semua mikroorganismenya lepas. Suspensi ini digunakan sebagai inokulum yang akan dimasukkan ke dalam medium fermentasi.

5. Pembuatan Medium Fermentasi

Medium yang masing-masing berisi selaput biji dan kulit markisa dalam bentuk tepung (8\%), $\mathrm{NaH}_{2} \mathrm{PO}_{4}(4.7 \%), \mathrm{CaCI}_{2}(0.1 \%), \mathrm{KCI}(0.02 \%), \mathrm{MgCI}_{2} .6 \mathrm{H}_{2} \mathrm{O}(0.02 \%)$, diatur pHnya menjadi 4.0, 4.5, 5.0, dan 5.5, kemudian ditambahkan buffer sitrat. Selanjutnya medium disterilkan pada otoklaf suhu $121{ }^{\circ} \mathrm{C}$ tekanan $2 \mathrm{~atm}$ selama 15 menit. Setelah medium dingin, diinokulasi dengan inokulum Aspergillus niger sebanyak $1 \mathrm{ml}$ pada volume medium $100 \mathrm{ml}$, difermentasikan pada shaker, suhu kamar dengan dua kali ulangan. Pengambilan sampel enzim dilakukan pada waktu fermentasi 3, 4, 5, dan 6 × 24 jam.

6. Penentuan Konsentrasi Glukosa Standar

Zat D - glukosa $200 \mathrm{mg}$ dilarutkan air suling sampai volume $1000 \mathrm{ml}$. Larutan dipindahkan ke dalam 11 tabung reaksi dengan volume yang ditentukan sebagai berikut: $0,0.2,0.4,0.6,0.8$, $1.0,1.2,1.4,1.6,1.8$, dan $2.0(\mathrm{ml})$. Ke dalam tiap-tiap tabung reaksi ditambahkan $1.6 \mathrm{ml}$ reagent Nelson A dan $0.4 \mathrm{ml}$ reagent Nelson B, kemudian dikocok. Semua tabung dipindahkan ke dalam water bath suhu $100{ }^{\circ} \mathrm{C}$ selama 10 menit dengan mulut tabung ditutup kelereng. Tabung-tabung dipindahkan ke air es selama 5 menit, kemudian ditambahkan ke dalamnya $2 \mathrm{ml}$ reagent arsenomolibdat dan $4.9 \mathrm{ml}$ air suling. Tabung dikocok sampai semua $\mathrm{CO}_{2}$ keluar, disentrifuge pada $5000 \mathrm{rpm}$ selama 10 menit. Kerapatan optis (serapan cahaya) diukur pada spektrofotometer dengan panjang gelombang $520 \mathrm{~nm}$. 
7. Penentuan Konsentrasi Glukosa Medium Fermentasi

Konsentrasi glukosa medium fermentasi ditentukan dengan urutan langkah sebagai berikut (Paleg, 1959):

a. Satu $\mathrm{ml}$ larutan $1 \%$ pati terlarut diisikan ke dalam 22 tabung reaksi, 21 tabung reaksi diinkubasikan dalam penangas air suhu $100^{\circ} \mathrm{C}$, dan 1 tabung untuk standar diinkubasikan ke dalam penangas air suhu $42{ }^{\circ} \mathrm{C}$, masing-masing selama 5 menit.

b. Ke dalam tabung yang telah diatur pHnya 5.0 ditambahkan $0.1 \mathrm{ml}$ enzim hasil pengenceran 10 kali (kecuali tabung reaksi untuk standar, ditambahkan $0.1 \mathrm{ml}$ air suling). kemudian diinkubasikan pada suhu pengujian $60{ }^{\circ} \mathrm{C}$. Reaksi dibiarkan selama 10 menit.

c. Setelah 10 menit, reaksi dihentikan dengan jalan memindahkan tabung-tabung tersebut ke dalam penangas air $100{ }^{\circ} \mathrm{C}$ selama 10 menit. Hasil hidrolisis selama 10 menit tersebut ditentukan konsentrasi glukosanya dengan metode Somogy-Nelson. Urutan langkah penentuan tersebut adalah sebagai berikut:

- Ke dalam masing-masing tabung reaksi ditambahkan $1.6 \mathrm{ml}$ reagen Nelson A, kemudaian $0.4 \mathrm{ml}$ reagen Nelson B. Campuran dikocok, kemudian mulut tabung ditutup kelereng dan dipanaskan dalam penangas air suhu $100^{\circ} \mathrm{C}$ selama 10 menit, kemudian didinginkan dalam es selama 5 menit.

- $\quad$ Ke dalam masing-masing tabung ditambahkan $2 \mathrm{ml}$ reagen Arsenomolibdat dan $4.9 \mathrm{ml}$ air suling. Tabung dikocok dengan kuat sambil menutup mulut tabung dengan ibu jari hingga seluruh gas $\mathrm{CO}_{2}$ keluar. Hasilnya disentrifuge pada $5000 \mathrm{rpm}$ selama 10 menit (jika terjadi endapan), kemudian diukur ODnya pada spektrofotometer dengan panjang gelombang $520 \mathrm{~nm}$.

\section{HASIL DAN PEMBAHASAN}

Penelitian ini dilakukan dengan memanfaatkan limbah markisa sebagai medium fermentasi untuk Aspergillus niger sehingga kapang tersebut dapat menghasilkan enzim amiloglukosidase yang dapat mendegradasi kandungan pati pada medium tersebut menjadi glukosa sebagai sumber karbon, sehingga dapat diserap masuk ke dalam selnya.

Proses fermentasi dilakukan pada medium cair, suhu kamar, variasi pada $\mathrm{pH}$ 4.0, 4.5, 5.0, dan 5.5, diesktraksi pada waktu fermentasi ke 3, 4, 5 dan 6 x 24 jam dengan menggunakan sentrifuge $3000 \mathrm{rpm}$ selama 10 menit. Dari analisis sidik ragam, degradasi pati oleh enzim amiloglukosidase memperlihatkan konsentrasi glukosa interaksi $\mathrm{pH}$ dan waktu fermentasi pada medium kulit dan selaput biji yang berbeda nyata pada taraf $1 \%$. Uji lanjut dengan Least Significant Difference (LSD) (Gomez and Gomez, 1983) memperlihatkan hasil seperti tampak pada tabel 1.

Tabel 1. Konsentrasi Glukosa Hasil Degradasi Pati 1\% oleh Enzim Amiloglukosidase dari Aspergillus niger Kombinasi Waktu Fermentasi dan $\mathrm{pH}$.

\begin{tabular}{cccc}
\hline \multirow{2}{*}{ NO } & PERLAKUAN & \multicolumn{2}{c}{ KONSENTRASI GLUKOSA $(\boldsymbol{\mu g} / \mathbf{m l})$} \\
\cline { 3 - 4 } & $($ Waktu Fermentasi dan $\mathbf{p H})$ & Kulit & Selaput Biji \\
\hline 1 & $\mathrm{~T}_{1} \mathrm{P}_{1}$ & $0.916 \mathrm{e} / \mathrm{x}$ & $16.083 \mathrm{e} / \mathrm{y}$ \\
\hline 2 & $\mathrm{~T}_{1} \mathrm{P}_{2}$ & $2.272 \mathrm{e} / \mathrm{x}$ & $20.359 \mathrm{de} / \mathrm{y}$ \\
\hline 3 & $\mathrm{~T}_{1} \mathrm{P}_{3}$ & $5.421 \mathrm{de} / \mathrm{x}$ & $10.236 \mathrm{f} / \mathrm{y}$ \\
\hline 4 & $\mathrm{~T}_{1} \mathrm{P}_{4}$ & $0.236 \mathrm{e} / \mathrm{x}$ & $7.026 \mathrm{f} / \mathrm{y}$ \\
\hline
\end{tabular}




\begin{tabular}{|c|c|c|c|}
\hline 5 & $\mathrm{~T}_{2} \mathrm{P}_{1}$ & $3.260 \mathrm{de} / \mathrm{x}$ & $26.347 \mathrm{~cd} / \mathrm{y}$ \\
\hline 6 & $\mathrm{~T}_{2} \mathrm{P}_{2}$ & $5.483 \mathrm{de} / \mathrm{x}$ & $38.384 \mathrm{~b} / \mathrm{y}$ \\
\hline 7 & $\mathrm{~T}_{2} \mathrm{P}_{3}$ & $7.828 \mathrm{~d} / \mathrm{x}$ & $31.470 \mathrm{c} / \mathrm{y}$ \\
\hline 8 & $\mathrm{~T}_{2} \mathrm{P}_{4}$ & $0.359 \mathrm{e} / \mathrm{x}$ & $25.174 \mathrm{~d} / \mathrm{y}$ \\
\hline 9 & $\mathrm{~T}_{3} \mathrm{P}_{1}$ & $21.470 \mathrm{ab} / \mathrm{x}$ & $41.470 \mathrm{~b} / \mathrm{y}$ \\
\hline 10 & $\mathrm{~T}_{3} \mathrm{P}_{2}$ & $22.828 \mathrm{ab} / \mathrm{x}$ & $51.964 \mathrm{a} / \mathrm{y}$ \\
\hline 11 & $\mathrm{~T}_{3} \mathrm{P}_{3}$ & $25.915 \mathrm{a} / \mathrm{x}$ & $50.298 \mathrm{a} / \mathrm{y}$ \\
\hline 12 & $\mathrm{~T}_{3} \mathrm{P}_{4}$ & $18.693 \mathrm{~b} / \mathrm{x}$ & $40.112 \mathrm{~b} / \mathrm{y}$ \\
\hline 13 & $\mathrm{~T}_{4} \mathrm{P}_{1}$ & $11.347 \mathrm{c} / \mathrm{x}$ & $23.878 \mathrm{~d} / \mathrm{y}$ \\
\hline 14 & $\mathrm{~T}_{4} \mathrm{P}_{2}$ & $21.223 \mathrm{ab} / \mathrm{x}$ & $30.112 \mathrm{~cd} / \mathrm{y}$ \\
\hline 15 & $\mathrm{~T}_{4} \mathrm{P}_{3}$ & $14.310 \mathrm{bc} / \mathrm{x}$ & $27.520 \mathrm{~cd} / \mathrm{y}$ \\
\hline 16 & $\mathrm{~T}_{4} \mathrm{P}_{4}$ & $9.001 \mathrm{~cd} / \mathrm{x}$ & $25.668 \mathrm{~d} / \mathrm{y}$ \\
\hline $\begin{aligned} \text { Keterangan : } \mathrm{T}_{1} & =3 \times 24 \mathrm{jam} \\
\mathrm{T}_{2} & =4 \times 24 \mathrm{jam} \\
\mathrm{T}_{3} & =5 \times 24 \mathrm{jam} \\
\mathrm{T}_{4} & =6 \times 24 \mathrm{jam}\end{aligned}$ & $\begin{array}{l}\mathrm{P}_{1}=\mathrm{pH} 4.0 \\
\mathrm{P}_{2}=\mathrm{pH} 4.5 \\
\mathrm{P}_{3}=\mathrm{pH} 4.0 \\
\mathrm{P}_{4}=\mathrm{pH} 5.5\end{array}$ & & \\
\hline
\end{tabular}

Pada tabel 1 tampak bahwa penggunaan substrat limbah markisa sebagai medium fermentasi dapat memacu Aspergillus niger untuk mengeluarkan enzim amiloglukosidase guna menguraikan pati yang terdapat pada substrat menjadi glukosa.

Hasil analisis pengukuran pada spektrofotometer panjang gelombang $520 \mathrm{~nm}$ dan berdasarkan persamaan regresi larutan glukosa standar $\mathrm{y}=0.10909+8.0909 .10^{-3} \mathrm{X}$, didapatkan konsentrasi glukosa tertinggi pada substrat kulit markisa adalah $25.915 \mu \mathrm{g} / \mathrm{ml}$, merupakan kerja enzim amiloglukosidase yang dihasilkan pada waktu fermentasi 5 x 24 jam pH 5.0. Hasil ini tidak berbeda nyata dengan beberapa perlakuan yaitu pada waktu fermentasi 5 x 24 jam pH 4.5 senilai $22.828 \mu \mathrm{g} / \mathrm{ml}$, waktu fermentasi $5 \times 24$ jam $\mathrm{pH} 4.0$ senilai $21.47 \mu \mathrm{g} / \mathrm{ml}$, dan waktu fermentasi 6 x 24 jam pH 4.5 senilai $21.223 \mu \mathrm{g} / \mathrm{ml}$.

Pada tabel 1 tampak bahwa konsentrasi glukosa tertinggi didapatkan pada substrat selaput biji yang merupakan kerja enzim amiloglukosidase pada waktu fermentasi 5 x 24 jam pH 4.5 senilai $51.964 \mu \mathrm{g} / \mathrm{ml}$ yang tidak berbeda nyata dengan perlakuan pada waktu fermentasi $5 \mathrm{x}$ 24 jam pH 5.0 senilai $50.298 \mu \mathrm{g} / \mathrm{ml}$.

Dari kedua jenis substrat yang digunakan, ternyata penggunaan selaput biji menghasilkan enzim yang mampu mendegradasi pati lebih banyak dibandingkan dengan substrat kulit untuk perlakuan yang sama (tabel 1 dan gambar 2). Ini disebabkan oleh kandungan polisakarida yang mengandung amilopektin pada kulit dapat menghambat kerja enzim karena ikatan rantainya panjang dan bercabang sehingga susah diuraikan. Sementara pada selaput biji, kandungan polisakaridanya hanya mengandung amilum dengan rantai lurus sehingga lebih mudah bagi enzim untuk menguraikannya. Walaupun demikian, kedua jenis substrat dari limbah markisa tersebut dapat digunakan sebagai medium fermentasi yang dapat merangsang Aspergillus niger menghasilkan enzim amiloglukosidase yang banyak digunakan untuk produksi alkohol, roti, juice, dan pati.

\section{KESIMPULAN}

1. Kandungan nutrien dalam limbah markisa dapat dimanfaatkan oleh Aspergillus niger sebagai medium fermentasi untuk menghasilkan enzim amiloglukosidase. Konsentrasi 
glukosa tertinggi didapatkan pada substrat selaput biji yang merupakan kerja enzim amiloglukosidase pada waktu fermentasi 5 × 24 jam pH 4.5 senilai $51.964 \mu \mathrm{g} / \mathrm{ml}$.

2. Substrat selaput biji markisa dapat dimanfaatkan oleh Aspergillus niger sebagai medium fermentasi lebih baik dibandingkan dengan substrat kulit markisa untuk menghasilkan enzim amiloglukosidase pada perlakuan yang sama.

\section{DAFTAR PUSTAKA}

Apa dan Bagaimana : Tentang Enzim. (2009). Jendela Informasi Sains. Sidoarjo: Science Areahttp://y121d1.blogspot.com/ (08-07-2009).

Aspergillus niger. (2007). Media Komunikasi Permi. Malang: Universitas Brawijaya. http://permimalang.wordpress.com/ (12-12-2007).

Djarre, M.T. Potensi Limbah Buah Markisa (Passiflora edulis Sims) Sebagai Bahan Makanan Ternak Ruminansia. (1994). Ujung Pandang: Fakultas Peternakan dan Perikanan Universitas Hasanuddin.

Dwidjosepoetro, D. (1978). Pengantar Mikologi. Bandung: Alumni.

Gaman, P.M., and K.B. Sherrington. (1992). llmu Pangan. Pengantar llmu Nutrisi dan Mikrobiologi. Terjemahan oleh Mardijati Gardjito, Yogyakarta: Gadjah Mada University Press.

Gomez, K.A. and A.A. Gomez. (1983). Statistical Producere for Agriculture Research. $2^{\text {nd }}$; New York: John Wiley and Sons Inc.

Hardjo, S., N.S Indrasti dan T. Bantacut. (1989). Biokonversi : Pemanfaatan Limbah Industri Pertanian Bogor: PAU Pangan dan Gizi IPB.

Indriani, R. Ine Dewi. (2001). Isolasi dan Penapisan Jamur Penghasil Glukoamilase dari Limbah Tapioka untuk Produksi Glukosa Cair dari Substrat Pati Mentah Ubi Jalar (Ipomoea batatas Lenk.) dan Ganyong (Canna edulis Kerr.). [Tesis] Bandung: ITB Central Library. http://digilib.itb.ac.id/ (2306-2008).

Kertesz, Z.I. and R.I. Me Collogen. (1976). Enzim Acting on Pectin Subtances dalam Tipson, R.S. and H. Derek, eds. Advances in Carbohydrat and Biochemistry. London: Academic Press.

Paleg, L.G. (1959). Citrit Acid Interference in the Estimation of Reducing Sugars with Alkalin Copper Reagens. Anal. Chem. 31, 1902 - 1904.

Pelczar, Michael J. dan E.C.S. Chan. (2006). Dasar-dasar Mikrobiologi 1. Terjemahan oleh R.S. Hadioetomo, dkk. Jakarta: Universitas Indonesia Press.

Popenoe, W. (1974). Manual of Tropical and Subtropical Fruit. New York: Hafner Press, A Division of Mac Millan Publishing Co. Inc.

Prescott, S.C. (1959). Industrial Microbiology. New York: Mc Graw Hill Publishing Company Ltd.

Rahman, A. (1992). Teknologi Fermentasi Industrial. Jakarta: Arcan.

Rismunandar. (1986). Mengenal Tanaman Buah-buahan. Bandung: Sinar Baru.

Sa'id, E.G. (1987). Bioindustri: Penerapan Teknologi Fermentasi. Jakarta: Mediyatama Sarana Perkasa.

Smith, J.E. (1993). Prinsip Bioteknologi. Terjemahan oleh V.F. Sumo, B. Sumantri, dan Subono. Jakarta: Gramedium Pustaka Utama.

Studi Suplai Industri Markisa Di Sulawesi Selatan. Smallholder Agribusiness Development Initiative, (2008). Makassar: SADI. http://www.sadi.or.id/ (01-06-2009).

Syamsu, Jasmal A. dan Syahriani. (1999). Daya Cerna In Vitro Kulit Buah Markisa (Passiflora edulis Sims) yang Disuplementasi dengan Urea Molases Blok. Prosiding Seminar Nasional II Ilmu Nutrisi dan Makanan Ternak, Bogor: Fakultas Peternakan Institut Pertanian Bogor dan Asosiasi Ilmu Nutrisi dan Makanan Ternak Indonesia (AINI) 147-148 ISSN 1410-4423. http://jasmal.blogspot.com.html (27 Mei 2009). 
26 _Jurnal Teknosains, Volume 13, Nomor 1, Januari-Juni 2019, hlm. 17- 26

Wood, Roff J.G. and B. Sinnluh. (1986). Commercial Fruit Processing. Westport, Connecticut: AVI Publishing Company Inc. 